\title{
Ultraviolet-absorbing organic anions in uremic serum separated by capillary zone electrophoresis, and quantification of hippuric acid
}

\author{
Citation for published version (APA): \\ Schoots, A. C., Verheggen, T.P. E. M., Vries, de, P. M. J. M., \& Everaerts, F. M. (1990). Ultraviolet-absorbing \\ organic anions in uremic serum separated by capillary zone electrophoresis, and quantification of hippuric acid. \\ Clinical Chemistry, 36(3), 435-440.
}

Document status and date:

Published: 01/01/1990

\section{Document Version:}

Publisher's PDF, also known as Version of Record (includes final page, issue and volume numbers)

\section{Please check the document version of this publication:}

- A submitted manuscript is the version of the article upon submission and before peer-review. There can be important differences between the submitted version and the official published version of record. People interested in the research are advised to contact the author for the final version of the publication, or visit the $\mathrm{DOI}$ to the publisher's website.

- The final author version and the galley proof are versions of the publication after peer review.

- The final published version features the final layout of the paper including the volume, issue and page numbers.

Link to publication

\footnotetext{
General rights

- You may freely distribute the URL identifying the publication in the public portal. follow below link for the End User Agreement:

www.tue.nl/taverne

Take down policy

If you believe that this document breaches copyright please contact us at:

openaccess@tue.nl

providing details and we will investigate your claim.
}

Copyright and moral rights for the publications made accessible in the public portal are retained by the authors and/or other copyright owners and it is a condition of accessing publications that users recognise and abide by the legal requirements associated with these rights.

- Users may download and print one copy of any publication from the public portal for the purpose of private study or research.

- You may not further distribute the material or use it for any profit-making activity or commercial gain

If the publication is distributed under the terms of Article 25fa of the Dutch Copyright Act, indicated by the "Taverne" license above, please 


\title{
Ultraviolet-Absorbing Organic Anions in Uremic Serum Separated by Capillary Zone Electrophoresis, and Quantification of Hippuric Acid
}

\author{
A. C. Schoots, ' T. P. E. M. Verheggen, ' P. M. J. M. De Vrles, ${ }^{2}$ and F. M. Everaerts'
}

Organic anions accumulated in blood serum of patients with chronic renal failure were separated by a novel technique: closed-system capillary zone electrophoresis (CZE) in a pH 6 carrier-electrolyte system. Hippuric acid (HA), p-hydroxyhippuric acid, and uric acid were identified by their co-elution with standards prepared in ultrafiltered normal serum and by comparison with the corresponding ultraviolet-detected peaks positively identified in the HPLC analyses. Analysis time for the entire profile is $8 \mathrm{~min}$. Repeatabilities (CVs) of CZE migration times and peak areas of the three acids in serum samples were about $0.7 \%$ and $6 \%$, respectively. We quantified HA in 10 ultrafiltered uremic serum samples and compared results with those by a previously described HPLC procedure. The very good agreement further supports the identification of hippuric acid. Accuracy and precision of the CZE method were similar to those for the HPLC gradientelution method, but analysis time for $\mathrm{HA}$ (8 $\mathrm{min})$ is much less than by HPLC (90 $\mathrm{min})$. Our technique is very suitable for selective, rapid analysis for (ultraviolet-absorbing) anionic constituents in ultrafiltered uremic serum, without any sample pretreatment.

Additional Keyphrases: renal function - tubular secretion anion gap - uremic toxins - HPLC compared - solvent effect

Substances that accumulate in the body fluids of patients with advanced impairment of renal function include aromatic or indolic compounds (e.g., phenols, phenolic acids, hippurates, indolic acids, amines), heterocyclic nitrogencontaining compounds (e.g., guanidines, creatinine, uric acid), trace elements (e.g., aluminum, nickel), low-molecular-mass proteins (e.g., $\boldsymbol{\beta}_{2}$-microglobulin, lysozyme, retinolbinding protein), parathyrin, potassium, and so-called middle molecules $(1-4)$.

Artificial methods for blood purification such as hemodialysis and continuous ambulatory peritoneal dialysis partly suppress or prevent the clinical symptoms observed in patients with advanced renal failure. Therefore, dialyzable toxins apparently must be directly or indirectly responsible for the multiple disorders observed in uremic patients. Until now, there has been no conclusive evidence for the toxicity of a single substance or a specific group of accumulating solutes. For the past 15 years, much attention has been paid to the "middle molecule" hypothesis (5), but this hypothesis is not convincingly supported by experimental evidence, partly because the "middle molecules" are ill-defined chemically $(3,6)$.

Various authors have pointed out the potential impor-

\footnotetext{
${ }^{1}$ Faculty of Chemical Engineering, SH2.05, Eindhoven University of Technology, P.O. Box 513, 5600 MB Eindhoven, The Netherlands.

2 Department of Internal Medicine, Renal Unit, Free University Hospital, Amsterdam, The Netherlands.

Received October 23, 1989; accepted December 4, 1989.
}

tance of organic anions that normally are excreted into urine by a highly efficient (proximal) tubular secretory mechanism in the kidney (7-9). These solutes inhibit cell-membrane ion transport in various tissues $(8,10)$. Recently, a multivariate statistical study showed that high concentrations of aromatic acids coincide with low nerveconduction velocities in patients on maintenance dialysis (11). Hippuric acid (HA), the aromatic acid regularly present at the highest concentration in uremic serum, may account for part of the positive anion-gap (12) observed in uremic patients and has been shown to inhibit drugprotein binding in (dialyzed) renal patients $(13,14)$. Hippurates are glycine conjugates formed in the liver from benzoic acids. Benzoic acid originates from the diet (fruits and vegetables, food preservatives), from mitochondrial $\beta$-oxidation of phenyl-fatty acids with an odd number of carbons, and from oxidative breakdown of phenylalanine through bacterial action in the intestines $(10,15,16)$. Furthermore, environmental contact with xylenes or toluenes results in increased HA concentrations in serum. Commercial heparin, frequently used in hemodialysis practice, may contain benzyl alcohol, the metabolism of which results in the generation of HA. Because HA may be a marker of accumulation of tubularly secreted organic acids (both endogenous and exogenous) and their glycine conjugates in the serum, it is important to develop reliable, rapid methods for detection and quantification of $\mathrm{HA}$ and other aromatic acids.

Organic acids in uremic serum can be analyzed, as a group, by use of temperature-programmed gas chromatography $(17,18)$ or "high-performance" liquid chromatography (HPLC) with gradient-elution $(9,19-21)$, both of which are relatively time-consuming procedures. Specific analysis for HA has also been done colorimetrically (22) and by HPLC (23), but these methods require sample pretreatment, such as extraction with organic solvents. Other methods used for selective isolation of urinary organic acids in general are anion-exchange and adsorption chromatography (24). Earlier we reported a preliminary study on the pre-separation of those anions present in uremic serum by isotachophoresis preceding HPLC (25). Here we describe a method for the rapid assay of anionic constituents in uremic serum by closed-system capillary zone electrophoresis (CZE), without sample pretreatment, and we compare results with those obtained with our HPLC method.

\section{Materials and Methods}

Serum and standard samples. Pre-dialysis blood, sampled from patients undergoing regular hemodialysis treatment, was allowed to clot before centrifugation, then stored at $-70^{\circ} \mathrm{C}$ until assay. Before analysis, the samples were deproteinized by centrifugal ultrafiltration (ambient temperature, $1500 \times g$ ) through micropartition ultrafiltration units (Grace \& Co., Amicon Div., Danvers, MA 01923). Thus, the HA concentrations measured represent the portion of HA not bound to serum proteins [36\% of HA in 
uremic serum is protein-bound (21)]. We prepared standard solutions for calibration in CZE and HPLC by adding HA to ultrafiltered normal (nonuremic) reference serum to give final concentrations in the injected calibration solutions of $0,12.5,25,50$, and $125 \mu \mathrm{mol} / \mathrm{L}$ for CZE analysis and 0,25 , 50,100 , and $250 \mu \mathrm{mol} / \mathrm{L}$ for HPLC analysis. Before injection, the ultrafiltered normal serum in these solutions was diluted 10-fold for CZE, fivefold for HPLC. These same dilution factors were used with the ultrafiltered uremic sera.

Capillary electrophoresis. For zone-electrophoresis experiments we used a home-made apparatus, described in detail elsewhere (26). The sampling unit has a fixed-volume (0.6 $\mu \mathrm{L})$ sampling compartment. For the separation compartment we used non-coated Teflon capillaries ( $200 \mu \mathrm{m}$ i.d.). The electrode compartments were separated from the separation compartment by semipermeable membranes. We used a slightly modified Model UV-M (Pharmacia, Uppsala, Sweden) fixed-wavelength ultraviolet-absorbance detector, operated at $254 \mathrm{~nm}$. During analysis, the electrical current was kept constant at 50 or $35 \mu \mathrm{A}$ and the voltage at about $10 \mathrm{kV}$. An Alpha-Series power supply (Brandenburg, Thornton Heath, U.K.) was used. Two carrier electrolyte systems were used (Table 1).

HPLC analyses were performed as described earlier (9, 21) but with a different separation column. We used a 4.6 $\mathrm{mm}$ (i.d.) $\times 25 \mathrm{~cm}$ Ultrasphere Octadecyl (C18-modified silica) column, packed with 5- $\mu \mathrm{m}$ particles, in conjunction with a $2 \mathrm{~mm}$ (i.d.) $\times 3 \mathrm{~cm}$ Ultrasphere Octadecyl guard column, packed with 10- $\mu \mathrm{m}$ particles (both from Beckman Instruments Inc., Fullerton, CA). The 45-min solvent gradient was linear from $100 \%$ aqueous ammonium formate buffer $(0.05 \mathrm{~mol} / \mathrm{L}, \mathrm{pH} 4)$ to $60 \%$ methanol $/ 40 \%$ buffer. The flow rate was $1 \mathrm{~mL} / \mathrm{min}$. The separation column and the solvent were kept at $25^{\circ} \mathrm{C}$ by means of a thermostated bath and column water jacket. The chromatograph consisted of a Model 421 controller, two Model 100A double-piston pumps, a Model 160 fixed-wavelength detector (wavelength $254 \mathrm{~nm}$, range $0.02 \mathrm{~A}$ full scale), and a Model 500 autosampler (all from Beckman Instruments). The injection volume was $25 \mu \mathrm{L}$.

Data acquisition and statistics. Zone-electrophoresis elution profiles and HPLC chromatograms were acquired with a chromatography data system. We used a Model 761S data interface and Model 2600 chromatography software (both from Perkin-Elmer/Nelson, Cupertino, CA) and an IBM $\mathrm{PC} / \mathrm{XT}$ computer. Sampling frequency was $10 \mathrm{~Hz}$ in CZE and $1 \mathrm{~Hz}$ in HPLC. For regression analysis we used the REG procedure from SAS statistical software (27).

Materials. 2-(N-Morpholino)ethanesulfonic acid and hip-

\begin{tabular}{lcc}
\hline $\begin{array}{c}\text { Table 1. Operational Systems Used in Capillary Zone } \\
\text { Electrophoresis } \\
\text { Syatem I }\end{array}$ & \multicolumn{1}{c}{ Syatem II } \\
Carrier constituent & Acetate & MES \\
Concn of carrier, mol/L & 0.01 & 0.01 \\
Counter constituent & $\beta-A l a n i n e$ & Histidine \\
pH & 3.8 & 6.1 \\
Additive & MHEC, $0.5 \mathrm{~g} / \mathrm{L}$ & MHEC, $0.5 \mathrm{~g} / \mathrm{L}$ \\
Capillary length, cm & 15 & 25 \\
Driving current, $\mu \mathrm{A}$ & 50 & 35 \\
- Teflon, $0.2 \mathrm{~mm}$ (i.d.). MES, 2(N-morpholino)ethanesulfonic acid. MHEC, \\
methylhydroxyethylcellulose.
\end{tabular}

puric acid were obtained from Sigma Chemical Co., St. Louis, MO 63178. Uric acid was from Merck AG, Darmstadt, F.R.G. We synthesized p-hydroxyhippuric acid by an active-ester method (28). Normal reference sera (Precinorm; Boehringer Mannheim, Mannheim, F.R.G.) were used for preparing the calibration solutions. Methylhydroxyethylcellulose (Serva, Heidelberg, F.R.G.) was used as a surface-active agent. For gradient-elution, we used "HPLCgrade" methanol (FSA Laboratory Supplies, Loughborough, U.K.). De-mineralized water was obtained with a Milli-Q water-purification system (Millipore/Waters, El Paso, TX 79998). Teflon capillaries [500 $\mu \mathrm{m}$ (o.d.), $300 \mu \mathrm{m}$ (i.d.)], were from Habia, Breda, The Netherlands, and were drawn over an inserted copper wire having an outer diameter of $200 \mu \mathrm{m}$ to give the desired inner diameter.

\section{Results and Discussion}

\section{Characteristics of the CZE Profiles}

Analytical zone electrophoresis in Tefion capillaries without electro-0smotic flow was introduced by Mikkers and colleagues $(29,30)$. Later on, Jorgenson and Lukacs (31) used borosilicate glass capillaries (75 $\mu \mathrm{m}$ i.d.) and electro-0smotic flow in their separations. Recently, gelfilled capillary columns were used (32) to separate biomolecules, exploiting sieving effects.

In our experiments, zone electrophoresis was performed as we have described. We added methylhydroxyethylcellulose to the carrier electrolytes and used an apparatus in which the Teflon capillary was separated from the electrode vessels by supported membranes, to suppress electro-0smotic effects. The ratio of zone electrophoretic and electroosmotic velocity can be expressed as follows:

$$
\frac{\nu_{z e}}{\nu_{e 0}}=-\frac{\epsilon \cdot \zeta}{\eta \cdot \mu}
$$

where $\epsilon$ is the dielectric constant, $\zeta$ the zeta-potential at the capillary surface, $\eta$ the dynamic viscosity, and $\mu$ the ionic mobility. If we assume a value of approximately $-1 \mathrm{mV}$ for the $\zeta$-potential at the Teflon surface in a pH 6 buffer system [a value measured earlier (33), for the analogous component hydroxyethylcellulose], we can calculate that the electroendosmotic "velocity," $\nu_{e 0}$, is only $1 \%$ of the zoneelectrophoretic velocity, $\nu_{x e}$. Hence, electroendosmosis would not be expected to influence the performance of the CZE analysis.

Uremic sera and standard solutions were analyzed by CZE and HPLC. Figure 1 shows zone electropherograms of a uremic serum ultrafiltrate analyzed in operational System I (pH 3.8) (Figure 1A) and in System II (pH 6) (Figure 1B) (see Table 1). In addition, the profile of an ultrafiltered normal serum, analyzed in System II, is shown (Figure 1C). In System I, with a low pH (3.8) of the carrier electrolyte, the weak organic acids in ultrafiltered uremic serum migrate much slower than in System II (pH 6). Uric acid (pK $=3.89$ ) did not pass the detector in a reasonable time (i.e., $20 \mathrm{~min}$ ) in this system, but was analyzed adequately in System II. The chromatogram shows that uric acid determination in human sera by CZE is promising. We have chosen the fast system shown in Figure $1 B$, to obtain a more complete anionic serum profile. Figure 2 shows the zone electropherogram and corresponding liquid chromatogram of an ultrafiltered uremic serum sample. Peaks tentatively identified in the figure legend were obtained 

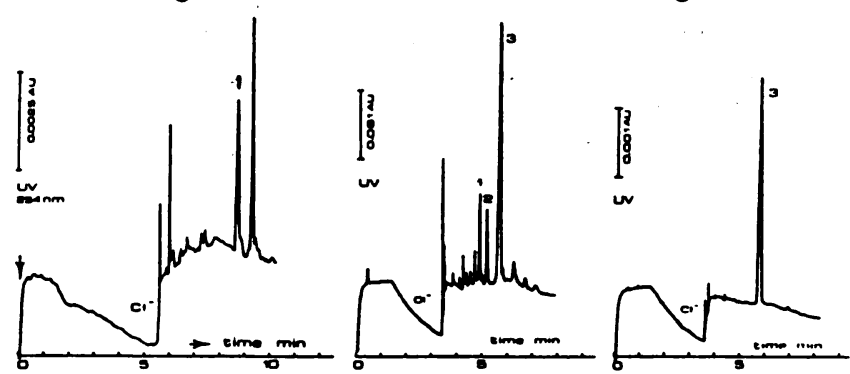

Fig. 1. Capillary zone electropherograms of $(A)$ uremic serum in $\mathrm{pH}$ 3.8 electrolyte (System I, Table 1), (B) uremic serum in pH 6 electrolyte (System II, Table 1), and (C) ultrafiltered normal serum in pH 6 carrier electrolyte (System II, Table 1)

Tentative peak identifications: 1, hippuric acid; 2, p-hydroxyhippuric acid; 3 , uric acid. Detection was at $254 \mathrm{~nm}$. Ultrafiltered serum was diluted 1:1 with water in $A, 1: 8$ in $B$ and $C$. " $A U$ " is $A$, absorbance
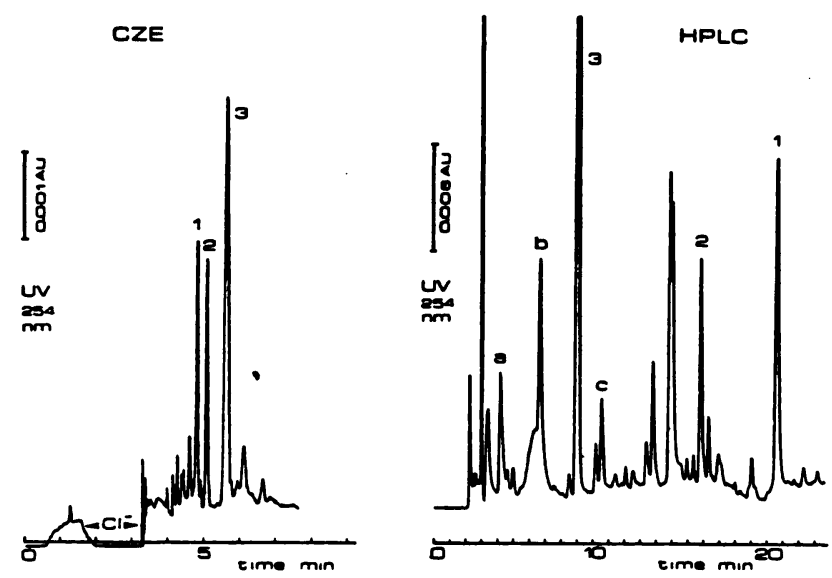

Fig. 2. Corresponding CZE and HPLC profiles for uremic serum ultrafiltrates

CZE analysis was done in System II (Table 1). Peak identifications common to both CZE and HPLC profile (tentatively in CZE) same as in Fig. 1. Other neutral or cationic compounds in HPLC: $a$, creatinine; $b$, pseudouridine; $c$, hypoxanthine. Note differences of ordinate scale and injection volumes $(0.6 \mu \mathrm{L}$ in CZE, $25 \mu \mathrm{L}$ in HPLC)

through co-elution of standards in CZE and, as reported earlier, by mass spectrometry and enzymatic peak shift in HPLC (4). Identification of the three prominent CZE peaks was supported by comparison with the prominent HPLC peaks, which were all detected at $254 \mathrm{~nm}$. HA was eluted at $t_{\mathrm{m}}=5 \mathrm{~min}$ in CZE and $t_{\mathrm{R}}=20 \mathrm{~min}$ in HPLC. Total analysis time for the profiles is $8 \mathrm{~min}$ in CZE and $90 \mathrm{~min}$ in HPLC. The length of the latter is due to the necessity of reequilibrating the HPLC column after gradient development, before the next sample is injected. It should be noted, however, that in the HPLC profile, neutral, anionic, and cationic constituents of serum are measured simultaneously, whereas CZE selectively separates anionic substances under the present conditions-which is desirable, because earlier studies (8) have shown that especially the group of tubularly secreted organic anions may be of importance in the etiology of uremic manifestations.

The CZE profiles show a large, asymmetrical negative peak starting at migration time of about $1.5 \mathrm{~min}$, which originates from the large amount of $\mathrm{Cl}^{-}$ions present in serum. Chloride is eluted as the first component because of its high absolute mobility of $80 \times 10^{-5} \mathrm{~cm}^{2} / \mathrm{N} \cdot \mathrm{s}$. Its concentration ordinarily is $110 \mathrm{mmol} / \mathrm{L}$ in serum water and varies only to a minor extent among most patients. This fact is of importance for the reproducibility of migration times. The presence of a major component in the injected sample may significantly influence migration times, as is illustrated in Figure 3. The electropherograms represent the analyses of diluted ultrafiltered sera to which different amounts of sodium chloride were added. The greater the amount of chloride added, the longer the migration times of the (other) sample constituents, the smaller their (diffusive) dispersion, and the closer their relative migration distances. Serum components eluting closely after the back edge of the chloride zone are very sharp, and peak-shape analysis, based on statistical moments, demonstrates theoretical plate numbers (34) of >1000 000 for these compounds. Plate numbers measured for low-molecular-mass solutes, injected in the absence of a major component, are about 30000 (26). We calculated that the plate number decreases rapidly with elution time for peaks eluting after the chloride zone. This delayed elution phenomenonwhich is related to the sample composition upon injection and which is analogous to the "solvent effect" observed in gel filtration and in gas and liquid chromatography (3538)-will be described elsewhere in more detail (Schoots et al., ms. submitted for publication). Peak heights of the minor components are higher when the amount of chloride added is greater (Figure 3). This "solvent effect," as expected, can be used to enhance detectability of specific (minor) sample constituents by adding a major component
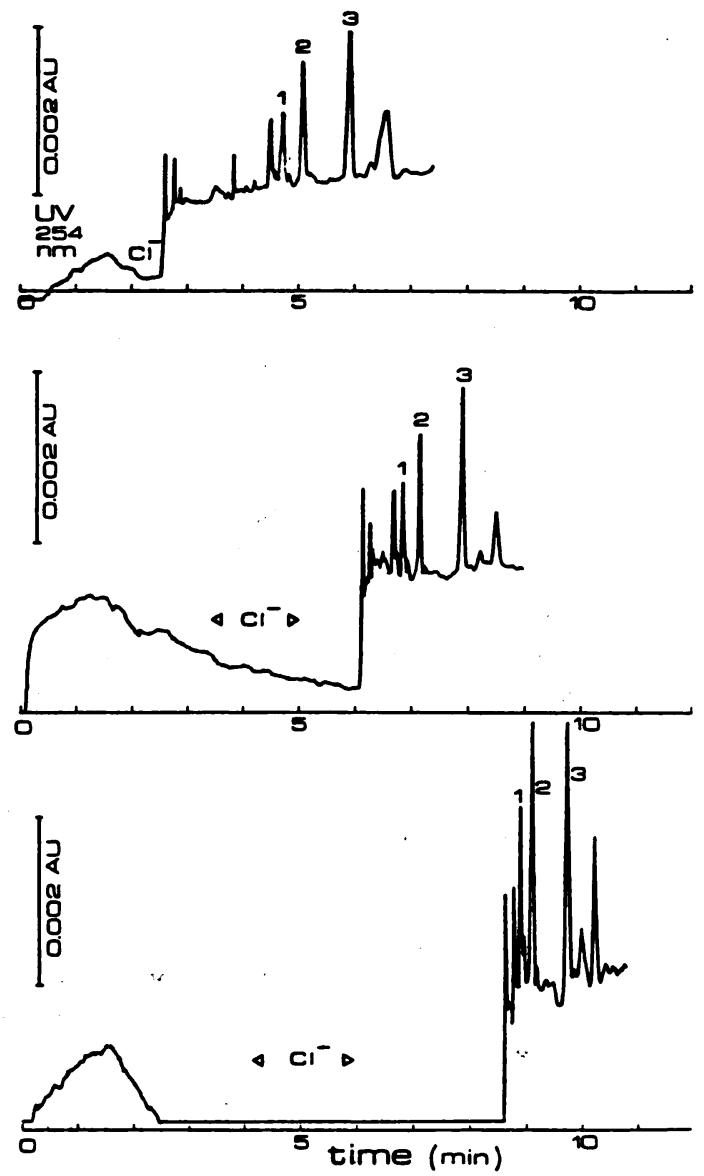

Fig. 3. Zone electropherograms (in System II; Table 1) of a 40fold-diluted ultrafiltered uremic serum sample with different amounts of sodium chloride added: (top) $2.8 \mathrm{mmol} / \mathrm{L}$ ( $\mathrm{n} \mathrm{Cl}^{-}$added), (middle) $13.2 \mathrm{mmoll}$, (bottom) $54.4 \mathrm{mmol}$

Tentative peak identifications same as in Fig. 1 
of appropriate nature and concentration.

The elution order for uric acid, $p$-hydroxyhippuric acid, and HA is reversed in CZE as compared with reversedphase HPLC. In HPLC, under the given conditions (C18modified silica, eluent pH 4) where the weak organic acids are only partly dissociated, the hydrophobic character of the solutes seems to determine the elution order: $t_{\mathrm{R}, \mathrm{UA}}<$ $t_{\mathrm{R}, \mathrm{PHHA}}<t_{\mathrm{R}, \mathrm{HA}}$. In the CZE experiments the following order of increasing effective ionic mobility was found for the three organic acids, as analyzed in ultrafiltered serum: $\mu_{\mathrm{UA}}<\mu_{\mathrm{PHHA}}<\mu_{\mathrm{HA}}$. The $\mathrm{p} K$ values $(2.700$, charge -1 ; 7.271, charge -2) and corresponding absolute mobilities $\left(25.3 \times 10^{-5}\right.$ and $55.1 \cdot 10^{-5} \mathrm{~cm}^{2} / \mathrm{V} \cdot \mathrm{s}$, respectively) of $\mathrm{HA}$ have been reported by Hirokawa et al. (39). The first $p K$ value, 2.7 , is lower than the value reported $(\mathrm{p} K=3.8)$ in another publication (40). Effective mobility, as is expressed in migration time, depends on several factors such as effective molecular radius, pK value, and concentration or activity coefficient. Moreover, secondary equilibria such as complexation influence effective mobility and thus migration time. Therefore, the discrepancy between reported $\mathrm{pK}$ values cannot be judged from the present data for serum samples; measurements under standardized conditions are necessary (41).

Table 2 shows the repeatability $(\mathrm{CVs})$ of migration times and peak areas in CZE of three components in uremic serum. At other concentrations these data are similar. Similar data have been reported earlier for the gradient HPLC analysis (20), the CVs being $0.6-1.0 \%$ and 3-6\% for retention times and peak heights, respectively.

HA was assayed in various concentrations in the series of ultrafiltered uremic serum samples, and the CV for its migration time in CZE was 2.5\% $(n=20$, all samples run on the same day).

\section{Quantification}

HA was quantified in $\mathbf{1 0}$ samples of ultrafiltered serum from uremic patients who were undergoing hemodialysis. The ultrafiltered serum samples were diluted 10 -fold before injection in the CZE procedure. The samples were all analyzed during one day, and calibration solutions were placed in between them. Peak area depends on migration velocity, because ultraviolet absorbance is a concentrationdependent detection principle. Therefore, in quantitative analysis based on peak area we used a constant electrical current, $35 \mu \mathrm{A}$, in all experiments. Quantification of HA by CZE was compared with quantification by HPLC, in which samples were diluted fivefold before injection. Injected amounts were $0.6 \mu \mathrm{L}$ in CZE, $25 \mu \mathrm{L}$ in HPLC-the latter being injected via an autosampler. For calibration, standard solutions were prepared by addition of HA to ultrafiltered normal serum (see Materials and Methods). Peak height is not linearly related to concentration in CZE under

Table 2. Repeatability of Migration Times, Peak Areas, and Peak Heights of Hippuric Acid, p-Hydroxyhippuric Acid, and Uric Acid in Ultrafiltered Uremic Sera $(n=5)$

\section{Component}

Hippuric acid p-Hydroxyhippuric acid Uric acid

\begin{tabular}{crrr}
$\begin{array}{c}\text { Moan } \\
\text { migration } \\
\text { time, } \min \end{array}$ & $\begin{array}{c}\text { Migration } \\
\text { time }\end{array}$ & $\begin{array}{c}\text { Peak } \\
\text { holght }\end{array}$ & $\begin{array}{c}\text { Peak } \\
\text { area }\end{array}$ \\
\cline { 2 - 4 } 5.07 & 0.86 & 4.9 & 6.4 \\
5.35 & 0.77 & 7.4 & 5.5 \\
5.88 & 0.73 & 4.5 & 6.5 \\
\hline
\end{tabular}

the present conditions, because solute peaks are intrinsically asymmetrical in CZE at these concentrations (i.e., $>1$ $\mu \mathrm{mol} / \mathrm{L})(30)$. The HA concentration range of the injected calibration solutions was 0 to $125 \mu \mathrm{mol} / \mathrm{L}$. Although CZE peaks were asymmetrical at these concentrations, this does not influence peak area as long as sufficient resolution from
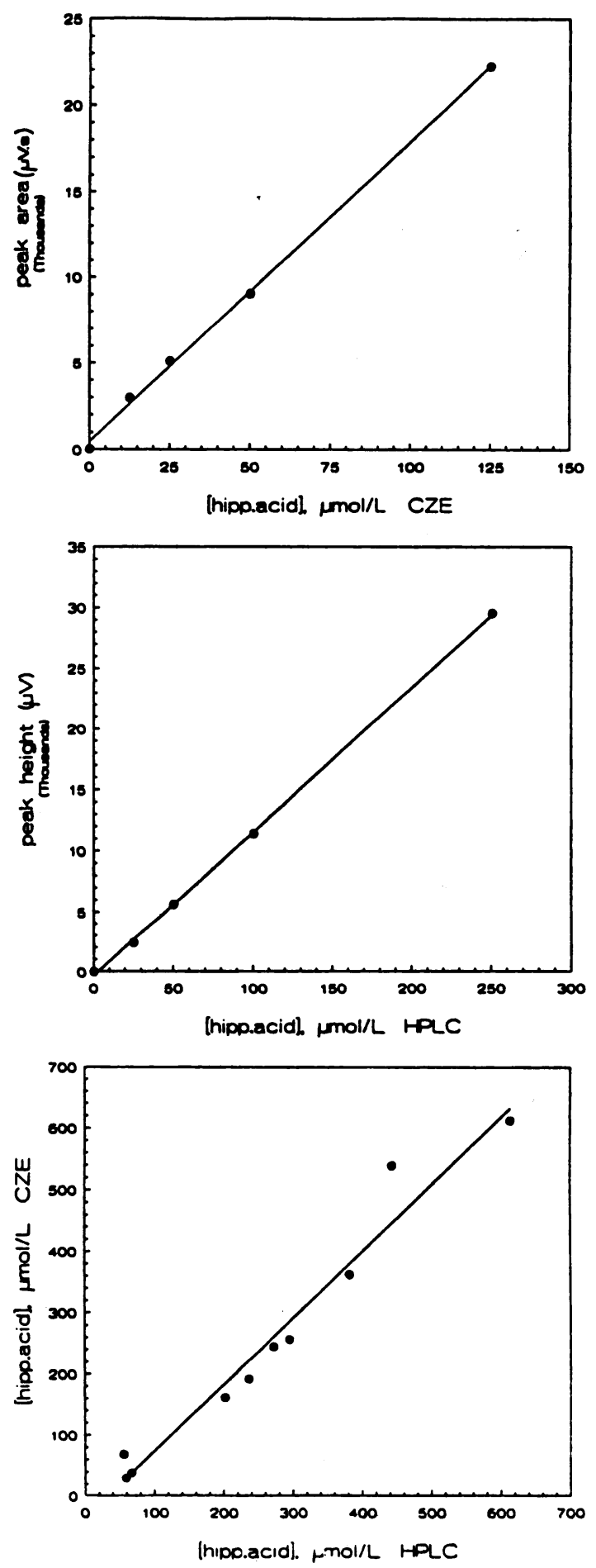

Fig. 4. Method comparison of quantification of HA in CZE and HPLC (bottom) and calibration lines for quantification by CZE peak area (top) and by HPLC peak height (middle)

Bottom: Abscissa and ordinate values were the mean of duplicate measurements in both CZE and HPLC, and are calculated as the concentrations in undifuted ultrafittered uremic sera. Top and middle: HA was added to norma reference serum 
other sample components is maintained. Therefore, HA concentrations up to $1250 \mu \mathrm{mol} / \mathrm{L}$ in ultrafiltered uremic serum can be measured because, in CZE, samples were diluted 10-fold before injection. Peak height has been found to be more reproducible than peak area in HPLC analysis (20). Therefore, peak area is used in CZE and peak height in HPLC. Calibration curves for HA in CZE and HPLC were obtained by injecting the calibration solutions in duplicate.

A linear model was fitted to the calibration data for HA, yielding the following relations:

$C Z E:$ Area $_{\mathrm{HA}}=437+174 \cdot\left(\right.$ concentration $\left._{\mathrm{HA}}\right)$; $r=0.999(P<0.0001)$.

HPLC: Height $_{\mathrm{HA}}=-481+60.83 \cdot\left(\right.$ concentration $\left._{\mathrm{HA}}\right)$; $r=0.999(P<0.0001)$.

The $y$-axis intercepts were not significantly different from zero (by $t$-test) in either CZE and HPLC.

We compared the present CZE technique with HPLC (9, 21), with respect to quantification of HA. Figure 4 shows the outcome of this comparative study. The ultrafiltered serum samples were analyzed in duplicate both in CZE and in HPLC, and the data points represent mean values for these determinations. We found a good agreement for the quantification of HA. The regression line shown in Figure 4 follows the equation Concn HA,CzE $=-35.16+$ $1.0860 \cdot\left(\right.$ Concn $\left._{\text {HA HPLC }}\right) ; r=0.981(P<0.0001)$.

The $y$-axis intercept was not significantly different from zero $(t=-1.475, P=0.18)$, nor was the slope of the regression line (1.086) significantly different from unity $(F$ $=1.29, P=0.29$ ).

\section{Conclusion}

The present study demonstrates the reliability of a new, rapid, and selective method of analysis for ultravioletabsorbing anionic constituents -especially HA-in uremic serum by CZE. The separation, based on differences in electrophoretic mobility of the anionic sample constituents, is therefore very suitable for the analysis of these types of compounds in uremic serum. HA, which is prominently present in uremic serum, can be quantified as accurately and precisely as with HPLC. Our method will facilitate the study of the usefulness of HA as a marker of accumulation of tubularly secreted organic acids and of its role in drugprotein binding in patients with chronic renal failure. The "solvent effect" we observed when there is a major component (chloride) in the injected sample may be useful for enhancing the detectability of minor components. Currently, commercial CZE equipment is available that enables organic acids in uremic serum to be resolved with even higher efficiency by use of separation capillaries with internal diameters of $75 \mu \mathrm{m}$ (or less) and involving electroosmotic flow (42).

\section{References}

1. Wills MR. Uremic toxins, and their effect on intermediary metabolism [Review]. Clin Chem 1985;31:5-13.

2. Schreiner GE, Maher JF. Uremia: biochemistry, pathogenesis, and treatment [Review]. Springfield, IL: Charles C Thomas, 1961:55-232.

3. Schoots A, Mikkers F, Cramers C, De Smet R, Ringoir S. Uremic toxins and the elusive middle molecules. Nephron 1984;38:1-8.

4. Schoots AC. Multicomponent analysis of accumulated solutes in uremia [Dissertation]. Eindhoven University of Technology, Eindhoven, The Netherlands, 1988.

5. Babb AL, Farrell PC, Uvelli DA, Scribner BH. Hemodialyzer evaluation by examination of solute molecular spectra. Trans Am Soc Artif Intern Organs 1972;28:98-105.
6. Schoots AC, Mikkers FEP, Claessens HA, De Smet R, Van Landschoot N, Ringoir SMG. Characterization of uremic "middle molecular" fractions by gas chromatography, mass spectrometry, isotachophoresis, and liquid chromatography. Clin Chem 1982; 28:45-9.

7. Smith HW, Finkelstein N, Aliminosa L, Crawford B, Graber M. The renal clearances of substituted hippuric acid derivatives and other aromatic acids in dog and man. J Clin Invest 1945;24:388404.

8. Grantham JJ, Whittier F, Diederich D. Uremia: strategies in the search for toxins. In: Andreoli TE, Hoffman JF, Fanestil DD, eds. Physiology of membrane disorders. New York: Plenum, 1978: 955-65.

9. Schoots AC, Dijkstra JB, Ringoir SMG, Vanholder R, Cramers CA. Are the classical markers sufficient to describe uremic solute accumulation in dialyzed patients? Hippurates reconsidered. Clin Chem 1988;34:1022-9.

10. Bourke E, Frindt G, Preuss H, Rose E, Weksler M, Schreiner GE. Studies with uraemic serum on the renal transport of hippurates and tetraethylammonium in the rabbit and rat: effects of oral neomycin. Clin Sci 1970;38:41-8.

11. Schoots AC, De Vries PMJM, Thiemann R, et al. Biochemical and neurophysiological parameters in dialyzed patients with chronic renal failure. Clin Chim Acta 1989;185:91-108.

12. Gabow PA. Disorders associated with an altered anion gap. Kidney Int 1985;27:472-83.

13. Gulyassy PF, Jarrard E, Stanfel L. Contributions of hippurate, indoxyl sulfate, and o-hydroxyhippurate to impaired ligand binding by plasma in azotemic humans. Biochem Pharmacol 1987;36:4215-20.

14. Vanholder R, Van Landschoot N, De Smet R, Schoots A, Ringoir S. Drug protein binding in chronic renal failure: evaluation of nine drugs. Kidney Int 1988;33:996-1004.

15. Stryer L. Biochemistry, 2nd ed. New York, NY: WH Freeman and Co., 1981:387 pp.

16. West ES, Todd WR, Mason HS, Van Bruggen JT, eds. Textbook of biochemistry. New York, NY: Macmillan Co., 1966:1453 pp.

17. Niwa T. Metabolic profiling with gas chromatography-mass spectrometry and its application to clinical medicine. J Chromatogr 1986;379:313-45.

18. Liebich HM, Pickert A, Tetschner B. Gas chromatographic and gas chromatographic-mass spectrometric analysis of organic acids in plasma of patients with chronic renal failure. J Chromatogr 1984;289:259-66.

19. Senftleber FC, Halline AG, Veening H, Dayton DA. Reversedphase liquid chromatographic analysis of hemodialysate from uremic patients. Clin Chem 1976;22:1522-7.

20. Schoots AC, Homan HR, Gladdines MM, Cramers CA, De Smet R, Ringoir S. Screening of UV-absorbing solutes in uremic serum by reversed-phase HPLC. Change of blood levels in different therapies. Clin Chim Acta 1985;146:37-51.

21. Schoots AC, Gerlag P, Mulder AW, Peeters JAG, Cramers CAMG. Liquid-chromatographic profiling of uremic solutes in serum of patients undergoing hemodialysis and chronic ambulatory peritoneal dialysis (CAPD); high concentrations of pseudouridine in CAPD patients. Clin Chem 1988;34:91-7.

22. Ohmori S, Ikeda M, Kira S, Ogata M. Colorimetric determination of hippuric acid in urine and liver homogenates. Anal Chem 1977;49:1494-6.

23. Igarishi P, Gulyassy P, Stanfel L, Depner T. Plasma hippurate in renal failure: high performance liquid chromatography method and clinical application. Nephron 1987;47:290-4.

24. Greter J, Jacobson CE. Urinary organic acids; isolation and quantification for routine metabolic screening. Clin Chem 1987;33:473-80.

25. Schoots AC, Everaerts FM. Isotachophoresis as a preseparation technique for liquid chromatography. J Chromatogr 1983;277:328-32.

26. Verheggen TPEM, Schoots AC, Everaerts FM. Feasibility of closed-system capillary zone electrophoresis. J Chromatogr (In press).

27. SASSTAT guide for personal computers, Version 6 edition. Cary, NC: SAS Institute Inc., 1985.

28. Van Brussel W, Van Summere C. $N$-Acylamino acids and peptides VI. A simple synthesis of $N$-acylglycines of the benzoyl- 
and cinnamoyl-type. Bull Soc Chim Belg 1978;87:791-7.

29. Mikkers FEP, Everaerts FM, Verheggen TPEM. Concentration distributions in free zone electrophoresis. J Chromatogr 1979;169:1-10.

30. Mikkers FEP. Isotachophoresis and zone electrophoresis in narrow-bore tubes [Dissertation]. Eindhoven University of Technology, Eindhoven, The Netherlands, 1980.

31. Jorgenson JW, Lukacs KD. High-resolution separations based on electrophoresis and electroosmosis. J Chromatogr 1981; 218:209-16.

32. Karger BL, Cohen AS, Guttman A. High performance capillary electrophoresis in the biological sciences [Review]. J Chromatogr 1989;492:585-614.

33. Reijenga JC, Aben GVA, Verheggen TPEM, Everaerts FM. Effect of electroosmosis on detection in isotachophoresis. $J$ Chromatogr 1983;260:241-54.

34. Giddings JC. Generation of variance, "theoretical plates," resolution, and peak capacity in electrophoresis and sodimentation. Sep Sci 1969;4:181-9.

35. Beling CG. Factors influencing the gel filtration of conjugated oestrogens. Acta Endocrinol 1963;43(Suppl 79):22-36.
36. Deans DR. The sample as its own stationary phase in gas chromatography. Anal Chem 1971;43:2026-9.

37. Grob K. On-column injection in capillary gas chromatography. Basic technique, retention gaps, solvent effects. Heidelberg: Huthig Verlag, 1987:245-355.

38. Kraak JC, Smedes F, Meijer JWA. Application of on-column concentration of deproteinized serum to the HPLC determination of anticonvulsants. Chromatographia 1980;13:673-6.

39. Hirokawa T, Nishino. M, Aoki N, et al. Table of isotachophoretic indices. I. Simulated qualitative and quantitative indices of 207 anionic substances in the range $\mathrm{pH}=3-10$. J Chromatogr 1983;271:1-106.

40. Weast RC, Astle MJ, eds. CRC handbook of chemistry and physics, 62nd ed. Boca Raton, FL: CRC Press, 1981:D142-3.

41. Beckers JL. Determination of absolute mobilities and $p K$ values by isotachophoresis. J Chromatogr 1984;320:147-58.

42. Schoots AC, Koomen GCM, Everaerts FM, Arisz L. Highresolution separations by capillary zone electrophoresis of accumulated solutes in body fiuids of patients with (chronic) renal failure [Abetract]. 2nd Int. Symp. on High Performance Capillary Electrophoresis, San Francisco, Jan. 29-31 (In press). 